\title{
Prevalence of iron deficiency anemia in infants in a Portuguese population
}

\author{
Cristiana Maximiano ${ }^{1}$, Mariana Portela $^{1}$, Juliana Almeida ${ }^{2}$, Alexandra Estrada ${ }^{2}$, Henedina Antunes ${ }^{1,3}$ \\ 1- Pediatric Gastroenterology, Hepatology and Nutrition Unit, Hospital de Braga, Braga, Portugal and Clinical \\ Academic Center (2CA), Braga, Portugal \\ 2- Clinical Pathology Department, Hospital de Braga, Braga, Portugal \\ 3- Life and Health Sciences Research Institute (ICVS), ICVS/3B's-PT Government Associate Laboratory and \\ School of Medicine, University of Minho, Braga, Portugal
}

Corresponding author:

Cristiana Maximiano, MD

Address: Sete Fontes - São Victor 4710-243 Braga, Portugal

Email: cristiana.maximiano@gmail.com

Phone: 00351919013542

\section{ABSTRACT}

\section{INTRODUCTION}

Iron deficiency is the world most prevalent nutritional disorder which is associated with impaired neurocognitive function in infants. The prevalence of iron deficiency anemia (IDA) in Portuguese infants remains unknown. The last study was performed by one of us (HA) in 1994 in a sample of 188 infants revealing a prevalence of IDA of 19\%. The main objective of this study is to determine the current prevalence of IDA in a sample of infants nine months of age in Braga, Portugal.

\section{METHODS}

This was a cross-sectional study on a random sample of infants born from September 2016 to February 2017 at Braga Hospital. They were evaluated for anthropometry, socio-economic factors, feeding regime and a blood sample was taken for blood cell counts, serum ferritin and $\mathrm{C}$ reactive protein.

\section{RESULTS}

Forty-two infants were included. The prevalence of IDA was $7.1 \%$. Nine infants were anemic (21\%); moderate anemia was observed in 2/9 of infants and mild anemia in 7/9 infants. Of the 3 infants with IDA, 2 had been exclusively breastfed until 6 months.

\section{CONCLUSIONS}

Compared to a study from 1994, there may have been a reduction in the prevalence of IDA in this area in Portugal.

Key-words: anemia; breastfed; iron deficiency; iron supplementation; nutrition disorder 


\section{INTRODUCTION}

Iron deficiency anemia (IDA) is the most common nutrient deficiency in the industrialized world, particularly among pre-school children, and there is evidence of an association with delayed mental development. ${ }^{1}$ IDA in infants remains underdiagnosed, as most infants do not undergo blood tests unless suggestive clinical signs are present. Further, these symptoms and signs--pallor, irritability, poor feeding, fatigue, lethargy, and pica--are non-specific. ${ }^{2}$ There is a clear association between IDA and impaired neurocognitive function with implications for intellectual function in childhood ${ }^{3}$, and this association continues even after its successful treatment. ${ }^{4}$

According to the World Health Organization (WHO) data, the prevalence of anemia and IDA remains high in late infancy and early childhood despite the increased breastfeeding rate, improvements in public health, and development of iron-fortified foods. ${ }^{5}$

The prevalence of iron deficiency may be as high as 30\% in toddlers from developed countries. ${ }^{6,7}$

The Portuguese prevalence of IDA in infants remains unknown. The most recent study was performed in 1994 in a sample of 188 infants aged nine months revealing a prevalence of $19.4 \% .^{8}$ About the study performed in 1994, the sample was consisting of the first 188 infants born during September to October'94 at São Marcos Hospital, in Braga, Portugal, with weight according to gestational age according to Lubchenco's reference curve for newborns. At about the same period in time, in Bristol, UK, Hopkins et al. ${ }^{1}$, using the anemia definition set forth by the WHO, hemoglobin [Hb] $<110$ $\mathrm{g} / \mathrm{L}$, found a prevalence of overall anemia of $23 \%$ at 8 months of age and $18 \%$ at 12 months of age.

The main objective of the present study is to determine the current prevalence of IDA in a sample of infants aged nine months and born in another hospital in Braga, Portugal.

\section{METHODS}

One hundred and fifteen infants of nine months of age, born at Braga's Hospital between September 2016 and February 2017, randomly chosen, were selected for this study. There were no exclusion criteria. However, the parents of only 42 infants both decided to participate in this study and attended the medical appointment. During consultation, infants were evaluated for anthropometry (weight, length and head circumference), socioeconomic factors, and feeding regime, a replication of the methods use in $1994 .{ }^{8}$ All these data were collected at the beginning of the appointment, through the administration of a questionnaire validated and agreed to by the Ethical Commission of Braga's Hospital. The anthropometry evaluation was performed using the same weight scale and tape measure for each child to minimize the possible error. Blood samples were taken for blood cell counts, serum ferritin and $\mathrm{C}$ reactive protein.

By WHO criteria, infants were labelled anemic if their hemoglobin level was less than $110 \mathrm{~g} / \mathrm{L}$, with IDA if, in addition, they had a ferritin value of less than $12 \mathrm{~g} / \mathrm{L}$, and the severity of anemia was defined according to patients' Hb levels: severe anemia, $\mathrm{Hb}<70.0$ g/L; moderate anemia, Hb 70.0-99.0 g/L; and mild anemia, Hb 100.0-109.0 g/L. ${ }^{9}$ 
Infants were considered to be supplemented with vitamin $C$ at home if they had received a daily dose of at least $15 \mathrm{mg}$ per day for at least three months. The infants diagnosed with IDA were treated with iron, $3 \mathrm{mg} / \mathrm{kg} /$ day for 3-6 mo.

Whole blood and serum samples were collected in EDTA and serum gel pediatric tubes (Sardstedt ${ }^{\circledR}$ ), respectively. A full blood count was performed using automated analyzers Sysmex XE 5000® and Sysmex XN 2000 ${ }^{\mathrm{TM}}$. Serum ferritin was determined by LOCI ${ }^{\circledR}$ technology and c reactive protein by nephelometry in a Siemens Dimension Vista $1500 \AA$ analyzer.

Data were analyzed using IMB SPSS Statistics 25.0 for Windows using non-parametric tests due the small sample. This study was approved by Ethical Committee of Braga's Hospital. All parents/guardians signed a consent form.

\section{RESULTS}

Forty-two infants were included in this study; 21 were females. All infants in this sample were healthy, full-term, and without history of intrauterine growth restriction or prematurity. All 42 infants were supplemented with vitamin D in appropriate doses and none had received vitamin $C$ supplementation. All mothers of these infants were supplemented with iron during pregnancy.

The prevalence of IDA was 7.1\%. The median hemoglobin in IDA group was $102 \mathrm{~g} / \mathrm{L}$ with median ferritin of $5 \mu \mathrm{g} / \mathrm{L}$. The differences seen in blood values between the infants with and without IDA were not statistically significant, probably in part due to the small sample size. See Table 1. In addition, there was no statistically significant difference for anthropometric values between groups with and without anemia.

Table 1 - Comparison of hematological values between infants with and without IDA

\begin{tabular}{|c|c|c|c|}
\hline & With IDA $(n=3)$ & Without IDA (n=39) & \\
\hline & $\begin{array}{l}\text { Median (minimum, } \\
\text { maximum) }\end{array}$ & $\begin{array}{l}\text { Median (minimum, } \\
\text { maximum) }\end{array}$ & p-value \\
\hline $\mathrm{Hb}(\mathrm{g} / \mathrm{L})$ & $102(9.6-10.4)$ & $116(9.8-13)$ & 0.367 \\
\hline Htc (\%) & $31.2(30.2-33)$ & $34.4(30.3-37.9)$ & 0.896 \\
\hline MGV (fL) & $62.5(58-71.2)$ & 75.6 (68.4-81) & 0.364 \\
\hline MGHC (g/dL) & $30.9(30.8-34.3)$ & 33.5 (31.8-37.3) & 0.837 \\
\hline RDW (\%) & 16.8 (12.7-19.3) & 13.4 (11.8-16.4) & 0.476 \\
\hline Ferritin $(\mu \mathrm{g} / \mathrm{L})$ & $5(3-10)$ & $29(13-66)$ & 0.966 \\
\hline $\begin{array}{l}\mathrm{C} \text { reactive protein } \\
(\mathrm{mg} / \mathrm{dL})\end{array}$ & 0 & $\begin{array}{l}6(0-15) \\
3 \text { infants had CRP }> \\
5 \mathrm{mg} / \mathrm{dL} \text { with normal } \mathrm{Hb} \\
\text { and ferritin }\end{array}$ & \\
\hline
\end{tabular}

Legend: Hb - Hemoglobin, Htc - Hematocrit, MGV - Mean Globular Volume, MGHC - Mean Cellular Hemoglobin Concentration, RDW - Red Cell Distribution Width, IDA - iron deficiency anemia

Nine infants were anemic (21.4\%). According to the WHO anemia classification, there were 2 cases of moderate anemia and 7 of mild anemia. 
Among the 3 infants with IDA, 2 were exclusively breast fed until 6 months. See in Table 2 the characterization of feeding regime and iron supplementation among the infants with IDA.

Table 2 - The characterization of fed regime and iron supplementation of infants with IDA

\begin{tabular}{|c|c|c|c|c|c|c|}
\hline & \multicolumn{3}{|c|}{ Fed regime until 6 months } & \multicolumn{3}{|c|}{ Fed regime at 9 months } \\
\hline & $\begin{array}{c}\text { Breast } \\
\text { fed }\end{array}$ & $\begin{array}{c}\text { Formula } \\
\text { fed }\end{array}$ & $\begin{array}{c}\text { Iron } \\
\text { supplementation }\end{array}$ & $\begin{array}{c}\text { Breast } \\
\text { fed }\end{array}$ & $\begin{array}{c}\text { Formula } \\
\text { fed }\end{array}$ & $\begin{array}{c}\text { Iron } \\
\text { supplementation }\end{array}$ \\
\hline $\begin{array}{l}\text { Patient } \\
1\end{array}$ & Yes & No & No & Yes & No & No \\
\hline $\begin{array}{l}\text { Patient } \\
2\end{array}$ & Yes & Yes & $\begin{array}{l}\text { Yes } \\
(2.5 \mathrm{mg} / \mathrm{kg} / \text { day })\end{array}$ & No & Yes & $\begin{array}{l}\text { Yes } \\
(1 \mathrm{mg} / \mathrm{kg} / \text { day })\end{array}$ \\
\hline $\begin{array}{l}\text { Patient } \\
3\end{array}$ & Yes & No & $\begin{array}{l}\text { Yes } \\
(2 \mathrm{mg} / \mathrm{kg} / \text { day })\end{array}$ & Yes & No & $\begin{array}{l}\text { Yes } \\
(1 \mathrm{mg} / \mathrm{kg} / \text { day })\end{array}$ \\
\hline
\end{tabular}

\section{DISCUSSION}

In our sample of nine-month old infants there may have been a reduction in the prevalence of IDA compared to the study from $1994 .^{8}$ During the last 15 years, the public health policies and population education about the importance of preventing IDA in infancy, initiating with iron supplementation during pregnancy and delayed umbilical cord clamping, all may have contributed to this apparently positive development. Risk factors associated with a higher prevalence of IDA include low birth weight, high cow's-milk intake, low intake of iron-rich complementary foods, and low socioeconomic status. ${ }^{11}$ According to Antunes et al., ${ }^{12}$ male gender is also an important clinical risk factor for iron deficiency in healthy infants.

Studies on anemia in infancy have been conducted in the United States ${ }^{13}$, Sweden ${ }^{14}$, Southeast Asia $^{15}$ and South Korea ${ }^{2}$, all finding that IDA in infants was more prevalent in boys than in girls age $<2$ years $\left(\mathrm{M}: \mathrm{F}=2 \cdot 14: 1^{2}\right)$. According to Antunes et al and Domellöf et al., at 9 months of age, male infants have significantly lower hemoglobin level and exhibit a 10-fold higher risk of being diagnosed with IDA than female infants. It was suggested that the reasons for increased IDA risk in the male infants were a higher preand post-natal growth rate, an increased fetal erythropoietic activity resulting in a low iron storage state, lower iron absorption, larger intestinal iron loss, and more frequent infections in boys than in girls. 8.14

From the age of 6 months, all infants and toddlers should receive iron-rich foods, including meat products and iron-fortified foods; unmodified cow's milk should not be the main milk drink to infants before the age of 12 month. ${ }^{11}$ According to Antunes et al., iron therapy can reverse some of the adverse effects in the development of children with IDA and therefore IDA prevention, screening and treatment can be justified. ${ }^{17}$ Of the developmental factors delayed by IDA, motor development seems to be the first to improve after iron therapy. ${ }^{18}$ 
Pediatricians should collect an accurate history of infant feeding practices (feeding type, the timing of weaning initiation, and contents of weaning food) during health screening visits, and should recommend blood tests to high-risk infants in order to facilitate the early detection of IDA.

The small sample was one major limitation of this study. Parents/guardians were at first very receptive to participating in the study, but the need to perform a venous puncture demotivated most of them. Larger studies in infants and toddlers in Portugal are necessary to assess and eventually improve iron nutritional status and to reduce IDA.

\section{REFERENCES}

1- Hopkins D, Emmett P, Steer C, et al. Infant feeding in the second 6 months of life related to iron status: an observational study. Arch Dis Child. 2007; 92:850-854.

2- Joo EY, Kim KY, Kim DH, et al. Iron deficiency anemia in infants and toddlers. Blood Research. 2016;51(4):268-273.

3- Carter RC, Jacobson JL, Burden MJ, et al. Iron deficiency anemia and cognitive function in infancy. Pediatrics. 2010;126:e427-e434.

4- Lozoff B, Jimenez E, Hagen J, et al. Poorer behavioral and developmental outcome more than 10 years after treatment for iron deficiency in infancy. Pediatrics. 2000;105:E51.

5- World Health Organization. The Global Prevalence of Anemia in 2011. Geneva, Switzerland: World Health Organization; 2015.

6- Looker AC, Dallman PR, Carroll MD, et al. Prevalence of iron deficiency in the United States. JAMA. 1997;277:973-976.

7- Soh P, Ferguson EL, McKenzie JE, et al. Iron deficiency and risk factors for lower iron stores in 6-24-month-old New Zealanders. Eur J Clin Nutr. 2004;58:71-79.

8- Antunes H, Costa-Pereira A, Cunha I, et al. Prevalência de anemia por deficiência de ferro de acordo com o tipo de alimentação do lactente. Acta Med Port. 2002; 15: 193-197.

9- Department of Nutrition for Health and Development (NHD) World Health Organization. Haemoglobin concentrations for the diagnosis of anaemia and assessment of severity. Geneva, Switzerland: World Health Organization; 2011.

10- Graffar M, Corbier J. Contribution to the study of the influence of socio-economic conditions in growth and development of the children. Ver Chil Pediatr. 1996;37:801-2.

11- Domellöf M, Braegger C, Campoy C, et al. ESPGHAN Committee on Nutrition, Iron Requirements of Infants and Toddlers. J Pediatr Gastroenterol Nutr. 2014, 58: 119-129.

12- Antunes H, Santos C, Carvalho S, et al. Journal of Eur Soc for Clin Nutr and Metab. 2012; 7:219222.

13- Lozoff B, Kaciroti N, Walter T. Iron deficiency in infancy: applying a physiologic framework for prediction. Am J Clin Nutr. 2006; 84:1412-142.

14- Domellöf M, Lönnerdal B, Dewey KG, et al. Sex differences in iron status during infancy. Pediatrics. 2002; 110:545-552.

15- Wieringa FT, Berger J, Dijkhuizen MA, et al. Sex differences in prevalence of anaemia and iron deficiency in infancy in a large multi-country trial in South-East Asia. Br J Nutr. 2007; 98:10701076.

16- Kolacek S, Koletzko B, Agostoni C, et al. Breast-feeding: A Commentary by the ESPGHAN Committee on Nutrition. J Pediatr Gastroenterol Nutr. 2009; 49 (1): 112-125.

17- Antunes H, Gonçalves S, Teixeira-Pinto A, et al. Does the effect of iron deficiency anaemia on development revert with iron therapy? J Pediatr Gastroenterol Nutr. 1999; 28 (5): 586.

18- Antunes H, Gonçalves S, Dinis-Ribeiro M, et al. Iron deficiency anemia: effects of iron therapy on infants’ development test performance. J Pediatr Gastroenterol Nutr. 1997; 24 (4): 492. 